\title{
圈 \\ Explaining Pension Fund Product and Governance Disclosure in Australia
}

Monica Guo-Sze Tan*1 and Marie-Anne Cam

\begin{abstract}
Fund disclosure is an important communication tool between trustees and fund members for product comparison and credibility verification. We examine what drives Australian not-forprofit superannuation funds to disclose their fund product information to the market. Our research derives a model that shows how the proprietary costs of disclosure and fund governance drive the disclosure of information about trustee, investment agents, fees, and overall practices. The research findings indicate that disclosure costs have a significant negative influence on voluntary disclosure, while board size has a weak positive relation with disclosure. Board independence is an unreliable and insignificant explanatory variable for voluntary disclosure. We discuss how the multi-layer agency relationship and institutional factors in the superannuation funds industry influence the power of these factors and their effects on voluntary disclosure.
\end{abstract}

Keywords: Fund disclosure; not for profit superannuation fund; superannuation; disclosure

JEL Classification: D14

* School of Economics, Finance and Marketing, RMIT University. Level 11, 445 Swanston Street, Melbourne VIC 3000 Australia.

${ }^{1}$ Corresponding Author; E-mail: monica.tan@rmit.edu.au. Telephone +61 39925 5880. Facsimile +61 39925 5624. 


\section{INTRODUCTION}

The superannuation industry is a significant segment of the Australian economy, occupying a vital role in its pension system and financial markets. While ensuring the long-term sustainability of Australia's retirement schemes, superannuation funds also represent powerful institutional investors who are able to make decisions that can have major impacts on Australia's economic development. On 1 July 2005, the Australian Government enacted new laws allowing employees to choose which fund will manage their contribution. As with any investment assessment, the decision to choose a superannuation fund relies on market data and the information disclosed by funds. The Australian Securities and Investments Commission (ASIC) and the Australian Prudential Regulation Authority (APRA) provide guidelines on the way superannuation funds disclose governance and product information via their product disclosure statements, financial statements and other promotional materials. The Superannuation Industry (Supervision) Regulations (SIS Act) 1994 and the Corporations Act 2001 requires superannuation funds to lodge regular financial disclosure, but the current disclosure by funds is inconsistent. There is currently a lack of "systematic transparency" in the superannuation funds industry; specifically, there is a lack of standardised methodology for the calculation and disclosure format of investment options, risk, return and costs of funds to provide quality information for any expert analysis (Cooper, 2010). Through our data collection, we found that although funds are required to disclose their costs, there is no information being reported to APRA in some cases. For example, some funds that appointed trustees disclosed zero trustee cost in their financial reports. The management fee and performance fee are reported in various formats (as a percentage or fixed fee) in funds' product disclosure statements and the calculation methods differ between funds. Furthermore, certain fees paid to related parties are not appropriately accounted for in the superannuation funds industry (Liu \& Arnold, 2010). A recent national review of the Australian superannuation system identifies disclosure as one of the key factors in ensuring superannuation funds operate effectively (Cooper, 2010). Of special interest is the quality of the disclosed information. For this paper, we measured the level of voluntary disclosure by funds using disclosure indices and conducted a cross-sectional analysis of what drives the level of disclosure for Australian industry and public sector superannuation funds. The findings suggest important implications for the choice of superannuation funds by employees, and the way forward in developing disclosure practices in the industry.

We focus on fund-specific factors that drive voluntary disclosure and argue that the decision to disclose is based on a fund's proprietary cost and governance arrangement. Agency problems and information asymmetry arise when the ownership of capital is separated from the control of decision-making (Jensen \& Meckling, 1976; Fama, 1980). This agency issue can be applied to equity and portfolio investments such as pension funds (superannuation funds, used interchangeably). Superannuation funds invest members' capital into financial products such as managed fund products. The financial product managers then act on behalf of the members by choosing the appropriate investment strategies based on the latter's mandates, while the capital that is invested remains the property of the members. This represents an analogous situation to an investment into an exchange-listed equity or fund where a fund manager invests the shareholders/stockholders' funds on the latter's behalf. With respect to disclosure, in both cases the investors or capital providers will evaluate and choose the funds based on information provided by the financial institution (fund managers or superannuation funds). "Agency and structural issues" are especially prominent in the 
Australian superannuation funds that are argued to deter market competition and the incentives for members to become effective monitors of their contributions (Cooper, 2010). A stringent regulatory environment promotes better disclosure practices, such as the case in the banking sector (Munir et al., 2011). Given the vagueness of current regulatory requirements, disclosure of superannuation fund information relies on the fund insiders (i.e. trustees and managers, who are the information holders). For this project, we examined the information in superannuation funds' annual reports, product disclosure statements, and websites to collect data for thirteen categories of information that are important in driving employees' decisions in choosing a fund to which they would contribute. These categories were selected due to information availability, and were closely related to a fund's agency issues, fees and performance, which were deemed as priorities for comparability between funds (Cooper, 2010). We developed three disclosure indices that measured the disclosure of superannuation funds' trustee boards, investment options and agents, and fee information, respectively. An Overall Disclosure Index, which consisted of the three indices, was calculated to assess the overall level of information disclosed to current members and potential new members, and compared to fund peers.

Our results show that trustee board size has a positive but weak effect on overall voluntary disclosure, and particularly disclosing investment options and agents' information. Board independence has a mixed effect on the various voluntary disclosure indices and the results are not significant. Disclosure costs measured by operating expenses influence all of the disclosure indices significantly and negatively except trustee board information. Fund type and size are not significant estimators of voluntary disclosure. We further conduct robustness checks using additional control variables, including whether a fund offers accumulation and public offer options, the number of trustee board committees and the percentage of pensioners in a fund. We find that the explanatory power of disclosure costs is robust in all indices, while the effect by board size varies. Our results are different to some of the past findings in the corporate governance and voluntary disclosure literature (Cheng \& Courtenay, 2006; Sanchez et al., 2011), indicating that external factors such as institutional environment and industry differences have an intimate interplay with internal factors on voluntary disclosure.

In the next section, we develop the literature review and hypotheses. The third section discusses our research methodology and the study's empirical results. The fourth section provides discussion of the findings, and the final section is our conclusion.

\section{LITERATURE REVIEW \& HYPOTHESIS DEVELOPMENT}

Voluntary disclosure can be driven by both internal (firm-specific) and external (institutional, regulatory and environmental) factors (Lopes \& Rodrigues, 2007). In this paper, we focus on how internal factors drive voluntary disclosure in superannuation funds. Disclosure and the transparency of superannuation funds management are crucial for effective communication between trustees and their members. These elements have both informative and educational purposes, with trustees presenting key information and justifying financial decisions to members. As the laws for superannuation choice are enacted, superannuation funds have a moral obligation to disclose useful information to facilitate decision-making by current and potential members. By 2010, since the introduction of the 2005 superannuation choice legislation, employees have had the choice of more than 196 funds, each providing multiple investment options. In such an environment, one would expect that the contributing 
employees will opt for superannuation funds that generate the highest returns, charge the lowest fees, are sustainable with their operations, and disclose information to confirm all of the above; hence, superannuation funds should disclose this information to the public so they can make informed decisions. For example, the "MySuper" option is proposed to offer a default option that standardises a number of features including the transparency of information that will improve comparability between funds (Cooper, 2010). Currently, there are two key obstacles that affect how employees make the choice of their superannuation funds. First, employees already in a fund may have to pay fees to switch to another provider. Second, a new employee is often encouraged to join a specific superannuation fund provider nominated by their employer, even though the employee is free to opt for another provider (Cooper, 2010). The Cooper Review (2010, p. 8) identifies that the "lack of information and transparency about fees and performance" combined with product complexity lead to the current weak competitive environment in the superannuation funds sector. In this market environment, we aim to explain what drives not-for-profit superannuation funds to disclose information to the market. We focus on examining superannuation funds' annual reports, product disclosure, and official websites to gauge the current levels of, and reasons for, disclosure. We use corporate governance and voluntary disclosure literature to develop our theoretical framework. We argue that the decision to disclose is a function of proprietary costs and trustee governance arrangement.

\subsection{Proprietary Costs and Fund Type}

By disclosing information, funds face the risk of sharing private strategic information of which competitors may take advantage (Darrough \& Stoughton, 1990). More specifically, disclosure could send signals indicating the value of, and developments within, a firm, product, or worker (Stiglitz, 1979). Verrecchia (1983) argues that disclosure costs (including dissemination and proprietary costs) are only incurred if a firm discloses information. On the other hand, Wagenhofer (1990) shows that the proprietary part of disclosure costs can be incurred even if a firm chooses not to disclose; this could result in a situation where a rival firm chooses to act upon nondisclosure signals to gain an advantage. Furthermore, Gigler (1994) argues that firms can create credibility for themselves, and influence the market and rivals' perceptions, to the disclosers' advantage by voluntarily disclosing high proprietary information if the information is not verifiable. When information is asymmetrical and research is costly, information holders (insiders) will choose to exploit information distribution to fulfil their own objectives; this, in turn, will affect product types, prices, demand, and supply of information in the market (Stiglitz, 1979). Disclosure is especially important in markets filled with dispersed ownership structures, where the monitoring of agents (management) by board of directors on behalf of shareholders is essential in mitigating shirking behaviours (Jensen \& Meckling, 1976). The agency problem in superannuation funds is widely discussed in a number of past research papers (Drew \& Standford, 2003; Coleman et al., 2006; Bateman \& Thorp, 2007; Bryan et al., 2009b; Benson et al., 2011). In superannuation funds, there is a vast pool of capital providers who do not manage and monitor their interests directly; this mimics the dispersed ownership structures in the equity market. The board of trustees, who have a similar role as the board of directors, monitors the appointment and performance of asset consultants and fund managers who represent the management of the funds on behalf of the members. Management influences accounting information, information type, and disclosure frequency based on their self-interest and 
constraints, which include taxes, regulations, political costs, disclosure costs, and the party with whom they engage (Watts \& Zimmerman, 1978; Leftwich et al., 1981).

The superannuation funds industry is divided into five main types: retail, corporate, industry, public sector, and self-managed. Each type is distinctive in terms of its strategies and target members. This has strong implications for proprietary costs as they vary among funds and types of funds. While the operation of each fund gives rise to its fund-specific proprietary costs, funds of the same type may share some similarities in their kinds and levels of costs. For example, Liu \& Arnold (2010) found that the number of conflicts of interest and the resultant fees arising from related party transactions were different between retail and notfor-profit superannuation funds in Australia; thus, the level of proprietary costs associated with voluntary disclosure will differ between fund types. Due to the presence of distinctive fund type-specific operational strategies and characteristics, funds of the same type may choose their level of voluntary disclosure collectively as this would reduce the proprietary costs between these funds. The costs for funds of the same type remain high compared to other types of funds as the latter will not gain any spill-over benefits from the former's disclosure (Simpson, 2008). Wagenhofer (1990) and Gigler (1994) also argue that partial voluntary disclosure of specific proprietary information will be undertaken if firms can deter rival advances in the market and achieve their objectives ex ante. Industry superannuation funds' advertising campaigns demonstrate this when they draw the public's attention to the costs and expenses of their organisations compared with the other types of funds, without comparing other performance parameters. Therefore, the type of fund affects the level of voluntary disclosure, and the direction of this effect is based on the type of specificity (i.e. agency and structural issues, and selection and representation of trustees) that a fund type has. That is, the higher the level of specificity a fund has, the higher the level of voluntary disclosure, because disclosing such information will not benefit other fund types.

Hypothesis 1: Voluntary disclosure differs according to fund type.

\subsection{Disclosure Costs and Valuation Benefits}

Voluntary disclosure incurs costs arising from information collection, administration, and dissemination, as well as proprietary costs (Simpson, 2008). The decision to disclose information to the market is based on the trade-off between disclosure costs and potential benefits derived (Simpson, 2008). We argue that the ultimate objective of a superannuation fund is to achieve long-term fund growth and sustainability; disclosure can potentially provide this benefit. Increasing fund size may potentially drive operating and investment costs down, which is an increased benefit for members. On the other hand, increased voluntary disclosure may drive operating costs up (due to the need to collect, administer and disseminate information). Moreover, as discussed earlier, proprietary costs may potentially increase the costs associated with voluntary disclosure depending on the type of fund and information being disclosed. Information users who are not familiar with disclosure rules and regulations are less likely to take disclosed information on face value (Khumawala et al., 2005). We do not expect the general public to be familiar with disclosure rules and regulations given that the current body of superannuation regulations and laws are complex and dissipated in various sources (Donald, 2011). Hence, members will scrutinise the information disclosed by funds when making their contribution decision. Funds would base their analysis of this trade-off between costs and benefits on past financial figures. High 
operating costs may influence a superannuation trustee to give priority to reducing costs through maintaining a low level of disclosure. On the other hand, if past performance shows a direct correlation between voluntary information disclosure and fund growth, funds may choose to increase their disclosure.

Hypothesis 2: Disclosure costs are negatively related to voluntary disclosure.

\subsection{Fund Governance}

The Cooper Review stipulates that governance models should affect all facets of fund operations and performance (Cooper, 2010). International studies have focused on fund governance as a critical issue in the management and performance of pension funds (Myners, 2000; Ambachtsheer et al., 2007; Stewart \& Yermo, 2008; Clapman, 2007). Depending on the level of financial literacy, members rely on the trustees to decide on the investment options from which they could choose from (Gallery et al., 2011). Furthermore, superannuation trustees appoint asset consultants and fund managers to operate their funds, while some funds may run an in-house asset management team. Trustees outsourced substantial fund operations including key decision-making areas such as strategic asset allocation and performance monitoring to consultants (Gupta et al., 2007; Sy et al., 2008). Specifically, trustees have the greatest input in selecting an administrator, asset consultant, setting objectives and risk tolerance, in this order of importance (Sy et al., 2008). Asset consultants and fund managers have their unique sets of private information that have a potential impact on fund returns (Drew \& Standford, 2003). Trustees play the role of fee negotiators with asset consultants and fund managers; hence, fund governance models affect the level of fees and operating expenses passed on to members (Bryan et al., 2009a). This multi-layer agency relationship complicates the determination of the level of proprietary costs in the superannuation industry. The proprietary costs may be associated with the ultimate information holder (namely, the fund manager), then are passed down to the asset consultants and trustees. At each agency level, information may or may not be fully disseminated at the discretion of the communicator. In order to perform a thorough assessment of information asymmetry, quality, and integrity, members will need to infer details from the information disseminated through the communication chain.

Fund governance measured in terms of the trustee board is an exogenous factor to fund disclosure, since trustees are currently paid a fixed fee that is not tied to funds' performance; our data shows, in some cases, trustee directors perform their roles on a voluntary basis (unless their fees were not recorded under trustee fees or reported properly in the APRA's financial data). We argue that the objectives of the trustees are to maximise the benefits to members and sustain fund growth and returns. It is the duty of trustees and directors to minimise the gap between the objectives of the superannuation funds and external agents with clear mandates and communication policies, effective monitoring, and reviews. Trustees, not management, are the main holders of information about the operations of superannuation funds. Hence, we focus on superannuation fund trustees as the information gatekeepers. 


\section{Board Size}

There is no study that empirically examines the characteristics of trustees on voluntary disclosure. In corporate governance, a larger board is related to better disclosure (measured in terms of earnings accuracy by analyst coverage) due to more consistent board operations and communication policies (Cheng, 2008; Byard et al., 2006). In another study, board size is found to have no association with voluntary disclosure (Cheng \& Courtenay, 2006), or the timeliness of earnings announcements (Bushman et al., 2004). Furthermore, Sanchez et al. (2011) argue that larger board size influences the effectiveness of control mechanisms and board monitoring efficiencies. Board size may be affected by fund size, growth rate, and merger activities. Nevertheless, we argue that, as a trustee board grows, there is an increased diversification of directors' expertise, a reduction in monitoring and information costs, and an improved balance in the representation of members' interests; all these lead to improved disclosure policies and practices, and better voluntary disclosure.

Hypothesis 3: Board size is positively related to voluntary disclosure.

\section{Independent Trustees}

Board composition is linked to disclosure, and the presence of independent directors can elicit contradictory outcomes. Where studies find independent directors contribute positively to the level of voluntary disclosure (Babío Arcay \& Muiño Vázquez, 2005; Cheng \& Courtenay, 2006), another argues these directors are negatively related to disclosure due to the substitution effect between the two (Eng \& Mak, 2003). In addition, the degree of information asymmetry between outside directors and firm insiders (such as the CEO), affects how the former could contribute to firm value; the high cost of information would reduce the value of outside directors to a firm (Duchin et al., 2010; Sanchez et al., 2011).

The SIS Act 1994 stipulates that the employer- and employee-nominated trustees must be equally represented in a fund; independent nomination can then be decided by the trustee board. We argue that better board independence can lead to a greater level of voluntary disclosure in superannuation funds. Independent trustees have better professional governance knowledge that can contribute to better disclosure and communication policies and practices. In addition, being an outsider, independent directors frequently collect and request information to perform their roles, this internalises information costs on behalf of fund members.

Hypothesis 4: Board independence is positively related to voluntary disclosure.

The following section discusses our methodology and the results from testing our hypotheses. 


\section{METHODOLOGY \& RESULTS}

We focus on trustee governance of the industry superannuation funds (industry superfunds) and public sector funds, both of which are currently under-researched. The industry and public sector funds' combined value of assets under management is the second largest, following the retail superannuation fund segment in the Australian superannuation industry. By 2010, these two categories of fund managed almost half of the assets under management in the sector ${ }^{1}$ with assets of AUD\$96.6 billion and AUD\$218.9 billion, respectively (compared with AUD\$47.5 and AUD\$330.4 billion for the corporate and retail sector funds) (APRA, 2011).

Table 1: Funds Sample Construction

\begin{tabular}{lcccccccc}
\hline & 2004 & 2005 & 2006 & 2007 & 2008 & 2009 & 2010 \\
\hline All APRA-regulated Industry and public sector superannuation funds & & & & \\
Industry & 75 & 77 & 71 & 69 & 65 & 63 & 60 \\
Public Sector & 23 & 23 & 22 & 20 & 20 & 19 & 20 \\
Funds excluded from the sample (non-surviving funds & or information & not disclosed & \\
Industry & 13 & 12 & 6 & 4 & 0 & 2 & 1 \\
Public Sector & 8 & 8 & 7 & 5 & 5 & 5 & 6 \\
Final sample & & & & & & & \\
Industry & 62 & 65 & 65 & 65 & 65 & 61 & 59 \\
Public Sector & 15 & 15 & 15 & 15 & 15 & 14 & 14 \\
Total number of funds in the final sample & $\mathbf{7 7}$ & $\mathbf{8 0}$ & $\mathbf{8 0}$ & $\mathbf{8 0}$ & $\mathbf{8 0}$ & $\mathbf{7 5}$ & $\mathbf{7 3}$ \\
\hline
\end{tabular}

The superannuation fund sample is initially drawn from official data provided by APRA, the government institution supervising superannuation funds. We started with a list of all APRA-regulated industry and public sector superannuation funds with more than four members. This sample excluded pooled superannuation, as well as exempted public sector superannuation schemes. The sample is further reduced as we excluded funds with nondisclosed financial information or non-surviving funds with fewer than three years of data. Based on our initial sample, we sought additional information using various sources. These included annual reports and press releases, which are considered important sources of information for firms (Gul \& Leung, 2009). When selecting and reviewing superannuation structure and performance, members and potential members rely on the product disclosure statement (PDS), annual reports, and official websites for information and comparisons across different funds. We used these sources as the main disclosure channels for funds to communicate with members and the market. In addition, corporations disclose information on the internet to reach a wider coverage of stakeholders and provide them with a timely and broad scope of information (Sanchez et al., 2011). In order to examine the current trustee governance structures, we collected information on trustee board size and independence. We also collected information about CEO-Chairman duality and dropped this variable given that this practice is not present in our sample. The information on superannuation funds governance is greatly limited and past years' records are usually not maintained on websites. Therefore, we collected the governance variables for the financial year 2009. Our sample suffers survival bias because past records of trustee information, annual reports and PDSs are

\footnotetext{
${ }^{1}$ Excluding self-managed funds, pooled superannuation trusts and public sector superannuation schemes.

${ }^{2}$ To protect the privacy of members, APRA did not disclose information on all the funds recorded.
} 
not maintained for public access by the funds or regulators. Information about trustees and board composition are fairly stable over a long period of time of at least 5 years (Gupta et al., 2007; Sy et al., 2008). We obtained industry and public sector superannuation funds financial data from APRA for the period 2004-2010. From this dataset, we extracted annual data on fund types, operating expenses and fund characteristics.

Table 2: Definitions of variables.

\begin{tabular}{|c|c|}
\hline Variable & Definitions \\
\hline Board size (bsize) & The total number of trustees per fund. \\
\hline Independence (pindpt) & The percentage of independent directors per fund. \\
\hline type & Fund type, where 1 = industry fund, 0 = public fund. \\
\hline Logopexp09 & $\begin{array}{l}\text { Natural log of fund's operating expenses (normalized by fund size) for } \\
\text { the year } 2009 \text {. }\end{array}$ \\
\hline Members09 & Natural log of fund's number of membership for the year 2009. \\
\hline Size09 & Natural log of fund size (end-of-year net assets) for the year 2009. \\
\hline $\begin{array}{l}\text { Board Disclosure Index } \\
(B D I)\end{array}$ & $\begin{array}{l}\text { The sum of the following, where the highest score is } 4 \text { points: } \\
1 \text { = trustee information is disclosed; } 0 \text { otherwise. } \\
1 \text { = trustee committee information is disclosed; } 0 \text { otherwise. } \\
1 \text { = directors' names are disclosed; } 0 \text { otherwise. } \\
1 \text { = nominator information is disclosed; } 0 \text { otherwise. }\end{array}$ \\
\hline $\begin{array}{l}\text { Investment Disclosure Index } \\
\text { (IDI) }\end{array}$ & $\begin{array}{l}\text { The sum of the following, where the highest score is } 4 \text { points: } \\
1 \text { = fund manager information is disclosed; } 0 \text { otherwise. } \\
1 \text { = asset consultant information is disclosed; } 0 \text { otherwise. } \\
1 \text { = investment allocation information are disclosed; } 0 \text { otherwise. } \\
1 \text { = investment option information is disclosed; } 0 \text { otherwise. }\end{array}$ \\
\hline Fee Disclosure Index (FDI) & $\begin{array}{l}\text { The sum of the following, where the highest score is } 5 \text { points: } \\
1 \text { = administrative cost information is disclosed; } 0 \text { otherwise. } \\
1 \text { = investment management fee information is disclosed; } 0 \text { otherwise. } \\
1 \text { = performance fee information are disclosed; } 0 \text { otherwise. } \\
1 \text { = withdrawal fee information is disclosed; } 0 \text { otherwise. } \\
1 \text { = investment switching fee information is disclosed; } 0 \text { otherwise. }\end{array}$ \\
\hline $\begin{array}{l}\text { Overall Disclosure Index } \\
(O D I)\end{array}$ & $\begin{array}{l}\text { The sum of BDI, IDI AND FDI: } \\
\text { ODI = BDI + IDI + FDI } \\
\text { Where the highest score is } 13 \text { points }\end{array}$ \\
\hline
\end{tabular}

Table 2 summarises the variables and their definitions as used in this paper. Board size (bsize) measures the total number of trustees per fund. Board independence (pindpt) is measured by the percentage of independent trustees per fund. Fund type (type) is a dummy variable to indicate whether a fund is an industry fund (value $=1$ ) or a public sector fund (value $=0$ ). Operating expenses, measured as the average operating expenses weighted by fund size (total asset value) per member, is a proxy for disclosure costs given the limitation of financial information reported by the superannuation funds and regulators. We correct for abnormal distribution in operating expenses, fund membership and size by applying natural $\log$ to the data. 
We follow Sanchez et al. (2011) and develop four unweighted disclosure indices using binary variables to measure the level of voluntary disclosure of various types of information. First, the Board Disclosure Index (BDI) measures the level each fund discloses about its trust and trustee identity, trustee committee structure, and trustee nomination. A point is allocated to each category of information with the highest score being 4 points and the lowest 0 for this index. The second index is the Investment Disclosure Index (IDI), which measures whether a fund discloses information about the identity of its fund managers and asset consultant, its investment allocation and investment options. A point is allocated if information is found; 4 points being the highest and 0 meaning no disclosure at all. The third index is the Fee Disclosure Index (FDI) that measures the level of fund disclosure associated with information of administrative cost, investment management fee, performance fee, withdrawal fee, and investment switching fee. There are five categories of information for this index where full disclosure is 5 points and no disclosure is 0 . The last index, the Overall Disclosure Index $(O D I)$ consolidates the previous three indices to give an overall disclosure measure of each fund. The maximum 13 points indicates full disclosure and 0 indicates no information is disclosed. The information for the disclosure indices is also collected from PDS, annual reports and websites for 2009.

Table 3: Descriptive statistics of variables.

\begin{tabular}{lcrrrc}
\hline & Mean & Minimum & Maximum & Std. Dev. & Observations \\
\hline bsize & 8.0000 & 4 & 17 & 2.7548 & 74 \\
pindpt & 0.0951 & 0 & 1 & 0.1730 & 70 \\
fundtype & 0.8148 & 0 & 1 & 0.3909 & 81 \\
ODI & 10.1852 & 0 & 13 & 3.5147 & 81 \\
BDI & 3.3210 & 0 & 4 & 1.0820 & 81 \\
IDI & 3.2469 & 0 & 4 & 1.2897 & 81 \\
FDI & 3.6173 & 0 & 5 & 1.5777 & 81 \\
logopexp09 & -8.8899 & -12.7169 & -3.4402 & 1.9633 & 75 \\
members09 & 10.66 & 6.51 & 14.49 & 1.76 & 75 \\
size09 & 13.82 & 9.03 & 17.13 & 1.60 & 75 \\
\hline bszer
\end{tabular}

bsize represents board size. pindpt represents the ratio of the number of independent directors to the total number of directors on a trustee board. fundtype represents fund type. ODI represents Overall Disclosure Index. BDI represents Board Disclosure Index. IDI represents Investment Disclosure Index. FDI represents Fee Disclosure Index. Logopexp09 represents natural log of operating expenses (normalised by fund size) for the year 2009. members09 represents the natural log of fund membership in 2009. size09 represents the natural log of fund size (end-of-year net assets value) in 2009. For the detail definitions of variables, refer to Table 1.

Table 3 describes our dataset. An average trustee board consists of eight trustees with the maximum size being seventeen seats, similar to past studies (Gupta et al., 2007; Sy et al., 2008). The overall level of board independence is low in the industry and public sector superannuation funds. Some trustee boards do not have independent trustees; on average, there is $9.5 \%$ board independence, with a small standard deviation of 0.1730 . An average fund incurred \$0.0010 operating expense per dollar of the fund's total assets per member in 2009, and little change is observed over time: an average of \$0.0012 between the period 2005 and 2009. On the other hand, fund membership in the industry and public sector superannuation funds has enjoyed an average growth of $11.54 \%$ between 2005 and 2009, with $0.03 \%$ growth recorded for the year 2009 . This is not to say that every fund has grown 
over time, which is indicated by a large standard deviation of 97.61; some funds have seen their membership shrink. The industry and public sector superannuation funds have performed well on average across all disclosure indices, with an average of: 3.3/4.0 in board disclosure $(B D I), 3.2 / 4.0$ in investment disclosure (IDI), 3.6/5.0 in fee disclosure (FDI) and 10.2/13.0 in overall disclosure (ODI).

Table 4 shows the correlations between variables. There is evidence to support the argument that internal governance mechanisms (such as the trustee board) have a relationship with disclosure practices. First, board size (bsize) has a significant and positive correlation with all disclosure indices; $0.3350(\rho<5 \%)$ with ODI, $0.3704(\rho<5 \%)$ with BDI, 0.2258 ( $\rho$ $<10 \%)$ with IDI and $0.2051(\rho<10 \%)$ with FDI. Second, board independence (pindpt) is negatively correlated with ODI (-0.2143, $\rho<10 \%)$, IDI $(-0.2332, \rho<10 \%)$ and FDI (0.2446, $\rho<5 \%$ ). This is inconsistent with the findings of Arcay and Vázquez (2005) and Gul and Leung (2009), but supports the argument of a substitution effect between independent directors and disclosure by Eng and Mak (2003). Fund operating expenses (logopex09) have significant and negative correlations with disclosure indices, except in the disclosure of trustee board information (BDI). This may be due to the equal representation rule that governs trustee board formation and the selection of trustees. In the industry and public sector superannuation funds with a paternalistic characteristic (Donald, 2011), where directors are often selected from the pool of members or nominated by employers and industry association, there may be existing trust in the trustee directorship by fund members; hence, no need arises to increase the transparency of the trustee structure and directors' profiles. Nevertheless, disclosure costs are a serious consideration when it comes to decisions about transparency. Fund type has no correlation with voluntary disclosure. The correlations between fund size measured in terms of total asset value and the number of members have mixed results with the various disclosure indices. Board size is correlated with fund size at the $1 \%$ significance level, while board independence has no correlation with any fund characteristic variables. This is an indication, perhaps, of a lack of role and contribution by independent trustees on the oversight of superannuation funds in the current structure.

Table 4: Correlations Table

\begin{tabular}{|c|c|c|c|c|c|c|c|c|c|c|}
\hline & 1 & 2 & 3 & 4 & 5 & 6 & 7 & 8 & 9 & 10 \\
\hline 1 & - & & & & & & & & & \\
\hline 2 & -0.1189 & - & & & & & & & & \\
\hline 3 & -0.1389 & $0.2832^{\dagger}$ & - & & & & & & & \\
\hline 4 & $0.3350^{\wedge}$ & $-0.2143 *$ & -0.1613 & - & & & & & & \\
\hline 5 & $0.3704^{\wedge}$ & 0.1171 & -0.0528 & $0.8125^{\wedge}$ & - & & & & & \\
\hline 6 & $0.2258 *$ & $-0.2332 *$ & -0.1370 & $0.9191^{\wedge}$ & $0.6502^{\wedge}$ & - & & & & \\
\hline 7 & $0.2051 *$ & $-0.2446^{\dagger}$ & -0.1736 & $0.9194 \wedge$ & $0.5928 \wedge$ & $0.7842^{\wedge}$ & - & & & \\
\hline 8 & -0.1714 & $0.4984^{\wedge}$ & $0.4894^{\wedge}$ & $-0.3161^{\wedge}$ & 0.0149 & $-0.3814 \wedge$ & $-0.3751^{\wedge}$ & - & & \\
\hline 9 & $0.4408^{\wedge}$ & -0.0234 & $-0.2766^{\dagger}$ & $0.3272^{\wedge}$ & $0.2507^{\dagger}$ & $0.2325 \wedge$ & $0.3395 \wedge$ & $-0.4561^{\wedge}$ & - & \\
\hline 10 & $0.5464 \wedge$ & -0.1690 & $-0.3197 \wedge$ & $0.2338^{\dagger}$ & 0.1602 & 0.1630 & $0.2578^{\dagger}$ & $-0.5144 \wedge$ & $0.8034 \wedge$ & - \\
\hline
\end{tabular}




\subsection{Regression Analysis}

Our research questions focus on voluntary disclosure in four categories of fund information in the Australian industry and public sector superannuation funds. We aim to explain what drives funds to disclose information about their trustee structure and composition, investment team and strategies, and fee structure.

To test our research question on voluntary disclosure of fund information, we developed four indices, namely $O D I, B D I$, IDI and FDI. Please see Table 2 for a detailed description of each index. Based on our literature review, we developed the following ordinary least square regression (OLS) model:

$$
\text { Disclosure }_{i}=\alpha_{i}+\beta_{1} \text { type }_{i}+\beta_{2} \text { opex }_{i}+\beta_{3} \text { bsize }_{i}+\beta_{4} \text { pindpt }_{i}+\beta_{5} \text { size }_{i}+\varepsilon_{i}
$$

where Disclosure is measured by ODI, BDI, IDI and FDI; type = fund type; opex = operating expenses, $b$ size $=$ trustee board size, pindpt $=$ the percentage of independent trustee per fund. We use two proxies for fund size (size): (1) end-of-year total asset value per fund; (2) end-ofyear total number of members per fund. We found the results between the two proxies are robust, hence we will only report the first proxy in our following result tables.

Table 5: This table shows the OLS results for Overall Disclosure Index (ODI), Board Disclosure Index $(B D I)$, Investment Disclosure Index (IDI) and Fee Disclosure Index (FDI). The estimators in the models include trustee type (type), normalised operating expenses (opex09), board size (bsize) and board independence percentage (pindpt). Fund size (logsize09) is a control variable. The standard errors reported in this table are white heteroskedasticity-consistent.

\begin{tabular}{|c|c|c|c|c|c|c|c|c|}
\hline \multirow{2}{*}{$\begin{array}{l}\text { Models } \\
\text { Variables }\end{array}$} & \multicolumn{2}{|c|}{ ODI } & \multicolumn{2}{|c|}{ BDI } & \multicolumn{2}{|c|}{ IDI } & \multicolumn{2}{|c|}{ FDI } \\
\hline & coef. & t-stat & coef. & t-stat & coef. & t-stat & coef. & t-stat \\
\hline Constant & 9.6937 & $\begin{array}{c}4.3555 \\
\left(2.2256^{\wedge}\right)\end{array}$ & 2.3077 & $\begin{array}{c}3.1964 \\
\left(0.7220^{\wedge}\right)\end{array}$ & 4.6067 & $\begin{array}{c}4.5909 \\
\left(1.0034^{\wedge}\right)\end{array}$ & 2.7793 & $\begin{array}{c}1.9929 \\
\left(1.3946^{\dagger}\right)\end{array}$ \\
\hline type & -0.2454 & $\begin{array}{l}-0.2207 \\
(1.1121)\end{array}$ & 0.0385 & $\begin{array}{c}0.1067 \\
(0.3607)\end{array}$ & -0.0378 & $\begin{array}{c}-0.0754 \\
(0.5014)\end{array}$ & -0.2461 & $\begin{array}{c}-0.3532 \\
(0.6968)\end{array}$ \\
\hline орех09 & -2.4601 & $\begin{array}{c}-3.0978 \\
\left(0.7941^{\wedge}\right)\end{array}$ & 0.1173 & $\begin{array}{c}0.4553 \\
(0.2576)\end{array}$ & -1.4048 & $\begin{array}{c}3.9235 \\
\left(0.3580^{\wedge}\right)\end{array}$ & -1.1726 & $\begin{array}{c}-2.3564 \\
\left(0.4976^{\dagger}\right)\end{array}$ \\
\hline bsize & 0.1686 & $\begin{array}{c}1.7801 \\
\left(0.0947^{*}\right)\end{array}$ & 0.0441 & $\begin{array}{c}1.4364 \\
(0.0307)\end{array}$ & 0.0900 & $\begin{array}{c}2.1087 \\
\left(0.0427^{\dagger}\right)\end{array}$ & 0.0344 & $\begin{array}{r}0.5800 \\
(0.0593)\end{array}$ \\
\hline pindpt & 0.5780 & $\begin{array}{c}0.4067 \\
(1.4211)\end{array}$ & 0.3332 & $\begin{array}{c}0.7228 \\
(0.4610)\end{array}$ & 0.3120 & $\begin{array}{c}0.4870 \\
(0.6407)\end{array}$ & -0.0673 & $\begin{array}{c}-0.0755 \\
(0.8905)\end{array}$ \\
\hline logsize09 & 0.0264 & $\begin{array}{r}0.1463 \\
(0.1802)\end{array}$ & 0.0674 & $\begin{array}{c}1.1521 \\
(0.0585)\end{array}$ & -0.1183 & $\begin{array}{l}-1.4554 \\
(0.0813)\end{array}$ & 0.0773 & $\begin{array}{c}0.6842 \\
(0.1129)\end{array}$ \\
\hline$F$-value & 5.9488 & & 1.5517 & & 6.0381 & & 4.2694 & \\
\hline $\begin{array}{l}\text { Adj R- } \\
\text { squared }\end{array}$ & 0.2757 & & 0.0407 & & 0.2793 & & 0.2010 & \\
\hline$P$ & 0.0002 & & 0.1876 & & 0.0001 & & 0.0022 & \\
\hline$N$ & 66 & & 66 & & 66 & & 66 & \\
\hline
\end{tabular}

*10\%, ${ }^{\dagger} 5 \%, \wedge 1 \%$ significance level. Heteroskadasticity-robust standard errors are shown in parentheses. 
Table 5 shows the OLS results for the four indices based on equation 1 . We report the heteroskadasticity-robust standard errors in parentheses. The results show that the short-term negative effect (coef.=-2.4601) on overall disclosure $(O D I)$ is significant at the $1 \%$ level for operating expenses. The result is consistent for IDI (coef.= -1.4048, $p<1 \%$; not significant in the model using fund membership as a fund size's proxy) and FDI (coef. $=-1.1726, p<5 \%$ ). Overall, we found that disclosure costs are the primary factor influencing funds' disclosure practices, with a negative relationship between disclosure costs and transparency, supporting H2. This also supports Simpson's (2008) notion of a trade-off between disclosure costs and the potential benefits derived. Board size has a positive effect on ODI (coef. $=0.1686, p<$ $10 \%$ ) and IDI (coef. $=0.0900, p<5 \%$ ). This supports H3. The combination of expertise and knowledge, and the dynamics of the working relationships and objectives of individuals may be different between an equal-presentation selection model and a merit-based selection model (as seen in the corporate sector); hence, our results diverge from the corporate governance literature. We do not find that fund type, board independence or fund size influence disclosure practices. Therefore, $\mathrm{H} 1$ and $\mathrm{H} 4$ are rejected. Our Variance Inflation Factor (VIF) scores for the estimators are below the threshold of 10; hence, no significant multicollinearity is present in our models.

\subsection{Robustness Tests}

We use four additional control variables in our robustness tests. Firstly, accumulation (accum) is a binary variable that takes the value of 1 if a fund offers the accumulation option; otherwise, it is 0 . An accumulation option differs from the defined benefit structure in which fund members can select and change their investment strategy (i.e. conservative, balanced or aggressive strategy) that they desire at any point in time. The offering of the accumulation option requires that funds disclose more relevant information to their members to assist the latter with their decision-making. The number of committees (ncomm) measures the number of committees that a fund trustee board has. Board committees assist trustees by providing them with specific areas of expertise and knowledge, thereby enhancing information collection and sharing in a fund's governance structure. The percentage of members who are pensioners (pension09) in a fund affects the investment options and products and operational costs, resulting in different communication strategies, information types, and collection and dissemination processes. Lastly, public offer ( $p o$ ) is a binary variable that takes the value of 1 if a fund opens its membership to the public (public offer fund); otherwise, it is 0. Under the SIS Act 1994, a public offer fund has to meet more stringent requirements in terms of the establishment of their trustee board, information disclosure to members and prospective members, and the level of member contribution. Hence, public offers may affect the voluntary disclosure practices of superannuation funds.

Table 6 shows the results of the robustness tests. We exclude the results for BDI because none of the models are significant. We found that disclosure costs (operating expenses) is a reliable and significant factor in explaining voluntary disclosure using $O D I$, IDI and FDI. In 10 out of 12 models, it has a negative effect at the $1 \%$ significance level on voluntary disclosure; one model shows a negative effect at the $5 \%$ significance level, while the other shows the same effect, but not significantly. Board size shows a consistently positive effect on voluntary disclosure in all three indices; however, the significance varies between 5\%, 10\%, and not significant at all. Fund type and board independence are both unreliable and not significant estimators of voluntary disclosure. The signs of their effects change in different models, yielding inconclusive results. The number of committees displays reliable positive effect on ODI, IDI and FDI; their significance level varies between $5 \%$ and $10 \%$ levels. This indicates that the trustee composition that gives rise to a collection of 
expertise and knowledge plays an important role in voluntary disclosure. Pension09 has a negative and significant effect on ODI, IDI and FDI, with levels of between $1 \%$ and $5 \%$. This indicates that a higher proportion of pensioners in a fund leads to lower voluntary disclosure. Public offer are significant at $1 \%$ with a positive effect on FDI, supporting the notion that by opening to public membership, funds are more proactive in disclosing information - in this case, about fees - to members and prospective members. Other control variables are found to have no significant effect on voluntary disclosure and their signs of effect are arbitrary.

\section{DISCUSSION}

Many past disclosure studies focus on the level of disclosure and how it affects firm value and investor behaviours. Derived from both Accounting and Finance literature, we explain what drives disclosure practices. We find voluntary disclosure of fund product information is affected by disclosure costs and, to a lesser extent, fund governance. Disclosure costs measured in terms of operating expenses has a significant and reliable influence over voluntary disclosure. Specifically, higher disclosure costs lead to a lower level of disclosure. Given that there is an increasing number of fund mergers over time in the Australian superannuation industry, funds are developing economies of scale in terms of membership and operating costs. Therefore, funds consider the trade-off between potential benefits and disclosure costs seriously and are able to manage the balance more effectively. Trustee board structure has less influence than trustee board composition in determining the level of voluntary disclosure. Trustee board structure measured by board size is to a large extent determined by fund size and the equal-representation rule in the nomination of trustees. This may deteriorate the natural effect of trustee board structure on voluntary disclosure as those seen in the corporate sector. Although we did not measure the profile and background of individual trustee, the number of board committees serves as a close proxy of trustee board composition and show significant positive effect on voluntary disclosure. This implies that the dynamics and interplay of expertise and knowledge among trustees in influencing decision-making are as important as in a corporate board of directors. More thorough research is required in this area.

We also demonstrate that different factors drive specific types of information. This supports the disclosure and information efficiency literature, which argues that the sharing of information is driven by the private objectives, abilities and constraints of the information holder (Verrecchia, 1983; Stiglitz, 1979; Darrough \& Stoughton, 1990; Gigler, 1994). We also show that the recipient of information may have a role in influencing the level and type of information that is disclosed. Our results show that the disclosure of fees is influenced by whether a fund is open to public membership. The disclosure of fees could be viewed by fund members to assess how efficiently a fund is being run. In not-for-profit entities, it is found that fund sponsors are mostly trusting about reported costs, especially in not scrutinising various classifications of 'joint-costs', such as those involved with fundraising, educational materials, and other operating expenses (Khumawala et al., 2005). Members in Australian superannuation funds may trust their trustees to act in their best interests under the paternalistic governance arrangement through the equal representation rule of trustee nomination. This, in turn, influences the type and quality of information being shared by the funds. 
Table 6: This table shows the robustness test results using OLS for Overall Disclosure Index (ODI), Investment Disclosure Index (IDI) and Fee Disclosure Index (FDI). The results for Board Disclosure Index $(B D I)$ are not reported due to the insignificance of all of the estimation models. The estimators in the models include trustee type (type), normalised operating expenses (opex09), board size (bsize) and board independence percentage (pindpt). Fund size (logsize09) is a control variable. Additional control variables are introduced separately in four models (1-4) to test the robustness of the estimators. The additional control variables include accum (dummy variable with 1 indicates that a fund has accumulation product; 0 otherwise); ncomm (the number of committees that a trustee board has); pension09 (the percentage of pension fund members in a fund); and po (dummy variable with 1 indicates that a fund has public offer; 0 otherwise). Only significant control variables are reported in the table. The standard errors reported in this table are white heteroskedasticity-consistent.

\begin{tabular}{|c|c|c|c|c|}
\hline & (1) accum & (2) ncomm & (3) pension09 & (4) po \\
\hline \multicolumn{5}{|l|}{ ODI } \\
\hline type & $(+)$, not significant & $(+)$, not significant & $(+)$, not significant & $(+)$, not significant \\
\hline орех09 & $(-), p<1 \%$ & $(-), p<1 \%$ & $(-), p<1 \%$ & $(-), p<1 \%$ \\
\hline bsize & $(+), p<10 \%$ & $(+)$, not significant & $(+)$, not significant & $(+), p<10 \%$ \\
\hline pindpt & $(+)$, not significant & $(-)$, not significant & (-), not significant & $(+)$, not significant \\
\hline logsize09 & (-), not significant & (-), not significant & $(+)$, not significant & $(-)$, not significant \\
\hline ncomm & - & $(+), p<10 \%$ & - & - \\
\hline pension09 & - & - & $(-), p<1 \%$ & - \\
\hline Adj. R-sq. & 0.2650 & 0.5257 & 0.3241 & 0.2764 \\
\hline Model p-value & 0.0004 & 0.0000 & 0.0000 & 0.0003 \\
\hline$N$ & 66 & 46 & 62 & 66 \\
\hline \multicolumn{5}{|l|}{ IDI } \\
\hline type & (-), not significant & (-), not significant & $(+)$, not significant & (-), not significant \\
\hline opex09 & $(-), p<1 \%$ & $(-), p<1 \%$ & $(-), p<1 \%$ & $(-), p<1 \%$ \\
\hline bsize & $(+), p<10 \%$ & $(+), p<10 \%$ & $(+), p<10 \%$ & $(+), p<5 \%$ \\
\hline pindpt & $(+)$, not significant & $(+)$, not significant & $(+)$, not significant & $(+)$, not significant \\
\hline logsize09 & $(-)$, not significant & $(-), p<10 \%$ & (-), not significant & $(-)$, not significant \\
\hline ncomm & - & $(+), p<10 \%$ & - & - \\
\hline pension09 & - & - & $(-), p<1 \%$ & - \\
\hline Adj. $R$-sq. & 0.2682 & 0.5505 & 0.2831 & 0.2738 \\
\hline Model p-value & 0.0004 & 0.0000 & 0.0003 & 0.0003 \\
\hline$N$ & 66 & 46 & 62 & 66 \\
\hline \multicolumn{5}{|l|}{ FDI } \\
\hline type & (-), not significant & (-), not significant & $(+)$, not significant & (-), not significant \\
\hline орех09 & $(-), p<5 \%$ & (-), not significant & $(-), p<1 \%$ & $(-), p<1 \%$ \\
\hline bsize & $(+)$, not significant & $(+)$, not significant & $(+)$, not significant & $(+)$, not significant \\
\hline pindpt & $(-)$, not significant & $(-), p<5 \%$ & $(-)$, not significant & $(-)$, not significant \\
\hline logsize09 & $(+)$, not significant & $(+), p<5 \%$ & $(+)$, not significant & $(-)$, not significant \\
\hline ncomm & - & $(+), p<5 \%$ & - & - \\
\hline pension09 & - & - & $(-), p<5 \%$ & - \\
\hline po & - & - & - & $(+), p<1 \%$ \\
\hline Adj. R-sq. & 0.1916 & 0.4036 & 0.3776 & 0.2515 \\
\hline Model p-value & 0.0044 & 0.0001 & 0.0000 & 0.0006 \\
\hline$N$ & 66 & 46 & 62 & 66 \\
\hline
\end{tabular}

The multi-layer agency relationship in the superannuation funds industry may have a significant impact on the level and quality of information being disclosed. Our results show that the explanatory power of board size on voluntary disclosure may be restricted by the 
equal-representation nomination rule. Therefore, disclosure is also driven by the institutional environment in which an entity is operating. In addition, the equal representation of employer- and employee-nominated directors undermines the role of independent trustees in the Australian superannuation funds. Trustees in public sector and larger funds tend to be more conformed in their beliefs and resistant to radical change (Gupta et al., 2007). Our evidence demonstrates that board independence has no influence on disclosure practices. Although some may argue that improving disclosure may not mitigate agency conflicts in the superannuation funds industry (Stewart \& Yermo, 2008), it is indisputable that disclosure practices are important ways for funds to communicate with members and the market, and an important source of information for product comparison and performance assessment. Via disclosure, market experts can also assess the credibility of the information providers and their associated agents (Gigler, 1994).

\section{CONCLUSION}

Our paper focuses on explaining what drives the disclosure of different types of product information in Australian industry and public sector superannuation funds. Our findings about the factors influencing voluntary disclosure of superannuation funds' product information shed light on the presence of agency conflicts and the future development of transparency in the industry. We draw on Accounting and Finance literature by combining the issues of proprietary information, disclosure costs and fund governance to develop our research model. Four disclosure indices examining the information disclosure of fund governance, investment, fees, and overall practices are developed and used in our regression models. We found evidence to support the hypotheses that disclosure costs and fund governance affect voluntary disclosure based on the type of disclosed information.

The Australian superannuation funds industry is segregated by fund type (that is, industry, public sector, corporate, retail, and self-managed funds). Hence, this results in inter-type and intra-type competition among the funds. This gives rise to a complex combination of proprietary costs for disclosure. Disclosure costs in terms of operating expenses have a significant and negative effect on disclosure practices. The size of the trustee board has a significant positive but weak impact on disclosure, while board independence, which is restricted by current institutional factors, has mixed results on voluntary disclosure.

Our study faced limitations in the availability of information about the Australian superfunds industry, and this had implications for the research methodologies we could employ to derive in-depth analyses. Nevertheless, we have provided a unique view of the superannuation industry and their levels of disclosure. We support the Cooper Review's (2010) view that governance is crucial in the operation of superannuation funds, including their disclosure practices. We highlight that trustee board composition, which affects the dynamic play between individual trustee's expertise and experience, plays a more significant role in voluntary disclosure than the trustee board structure. In addition, disclosure is driven by the institutional environment, the selection process of trustees and structure of funds (such as whether a fund is open to the public). In their effort to promote market competition and improve fund comparability, policy-makers must take into consideration the endogenous and exogenous factors that affect funds' disclosure practices. A standardised disclosure framework may improve comparability between funds, but this should not lead to a prescriptive governance framework across all funds as each fund possesses unique characteristics and structures. Therefore, funds should be allowed some flexibility to implement governance practices that are relevant to them, but be required to disclose 
information in a systematic format to enhance information symmetry in the industry. Further directions for research in this area could address understandings of trustee governance and their impact on fund returns and risk management.

\section{REFERENCES}

Ambachtsheer, K., Capelle, R. \& Lum, H. 2007. The State of Global Pension Fund Governance Today: Board Competency Still a Problem. Toronto: Rotman International Centre for Pension Management.

APRA 2011. Superannuation Fund-level Rates of Return June 2010. Barton ACT: Australian Prudential Regulation Authority.

Arcay, M. \& Vazquez, M. 2005. Corporate Characteristics Governance Rules and The Extent of Voluntary Disclosure in Spain. Advances in Accounting, 21, 299-331. http://dx.doi.org/10.1016/S0882-6110(05)21013-1

Babío Arcay, M. R. \& Muiño Vázquez, M. F. 2005. Corporate Characteristics, Governance Rules and the Extent of Voluntary Disclosure in Spain. Advances in Accounting, 21, 299-331. http://dx.doi.org/10.1016/S0882-6110(05)21013-1

Bateman, H. \& Thorp, S. 2007. Decentralised investment management: an analysis of nonprofit pension funds. Journal of Pension, Economics and Finance, 6, 21-44. http://dx.doi.org/10.1017/S1474747206002484

Benson, K. L., Hutchinson, M. \& Sriram, A. 2011. Governance in the Australian Superannuation Industry. Journal of Business Ethics, 99, 183-200. http://dx.doi.org/10.1007/s10551-010-0648-1

Bryan, D., Considine, G., Ham, R. \& Rafferty, M. 2009a. Agents with Too Many Principals? An Analysis of Occupational Superannuation Fund Governance in Australia. Workplace Research Centre, University of Sydney,.

Bryan, D., Ham, R., Rafferty, M. \& Yoon, K. 2009b. Governance and Performance in the Australian Occupational Superannuation Industry. In: TRUSTEES, A. I. O. S. (ed.) Fund Governance in the Representative Trustee Sector. Australian Institute of Superannuation Trustees and Workplace Research Center (University of Sydney).

Bushman, R., Chen, Q., Engel, E. \& Smith, A. 2004. Financial accounting information, organizational complexity and corporate governance systems. Journal of Accounting and Economics, 37, 167-201. http://dx.doi.org/10.1016/j.jacceco.2003.09.005

Byard, D., Li, Y. \& Weintrop, J. 2006. Corporate governance and the quality of financial analysts' information. Journal of Accounting and Public Policy, 25, 609-625. http://dx.doi.org/10.1016/j.jaccpubpol.2006.07.003

Cheng, E. C. M. \& Courtenay, S. M. 2006. Board composition, regulatory regime and voluntary disclosure. The International Journal of Accounting, 41, 262-289. http://dx.doi.org/10.1016/j.intacc.2006.07.001

Cheng, S. 2008. Board size and the variability of corporate performance. Journal of Financial Economics, 87, 157-176. http://dx.doi.org/10.1016/j.jfineco.2006.10.006 
Clapman, P. 2007. Committee on Fund Governance - Best Practice Principles. The Standford Institutional Investors' Forum: Stanford Law School and The Rock Center for Corporate Governance.

Coleman, A. D. F., Esho, N. \& Wong, M. 2006. The impact of agency costs on the investment performance of Australian pension funds. Journal of Pension, Economics and Finance, 5, 299-324. http://dx.doi.org/10.1017/S1474747205002350

Cooper, J. 2010. Super System Review Final Report. Barton: Commonwealth of Australia.

Darrough, M. N. \& Stoughton, N. M. 1990. Financial disclosure policy in an entry game. Journal of Accounting and Economics, 12, 219-243. http://dx.doi.org/10.1016/0165$\underline{4101(90) 90048-9}$

Donald, M. 2011. What contribution does trust law make to the regulatory scheme shaping superannuation in Australia? Australian Prudential Regulation Authority.

Drew, M. E. \& Standford, J. D. 2003. Policy Forum: Is Superannuation Safe? Principal and Agent Problems in Superannuation Funds. Australian Economic Review, 36, 98-107. http://dx.doi.org/10.1111/1467-8462.00270

Duchin, R., Matsusaka, J. G. \& Ozbas, O. 2010. When are outside directors effective? Journal of Financial Economics, 96, 195-214. http://dx.doi.org/10.1016/j.jfineco.2009.12.004

Eng, L. L. \& Mak, Y. T. 2003. Corporate governance and voluntary disclosure. Journal of Accounting and Public Policy, 22, 325-345. http://dx.doi.org/10.1016/S0278$\underline{4254(03) 00037-1}$

Fama, E. F. 1980. Agency problems and the theory of the firm. The Journal of Political Economy, 88, 288-307. http://dx.doi.org/10.1086/260866

Gallery, N., Newton, C. \& Palm, C. 2011. Framework for Assessing Financial Literacy and Superannuation Investment Choice Decisions. Australasian Accounting Business \& Finance Journal, 5, 3-22.

Gigler, F. 1994. Self-Enforcing Voluntary Disclosures. Journal of Accounting Research, 32, 224-240. http://dx.doi.org/10.2307/2491283

Gul, F. A. \& Leung, S. 2009. Board leadership, outside directors' expertise and voluntary corporate disclosures. Journal of Accounting and Public Policy, 23, 351-379. http://dx.doi.org/10.1016/j.jaccpubpol.2004.07.001

Gupta, V., Jin, H., Orszag, M. \& Piggot, J. 2007. How do Australian Superannuation Fund trustees Perceive their Role and Effectiveness? : Australian Institute for Population Ageing Research, University of New South Wales.

Jensen, M. C. \& Meckling, W. H. 1976. Theory of the firm: Managerial behavior, agency costs and ownership structure. Journal of Financial Economics, 3, 305-360. http://dx.doi.org/10.1016/0304-405X(76)90026-X

Khumawala, S. B., Gordon, T. P. \& Parsons, L. 2005. Assessing the Quality of Not-for-Profit Efficiency Ratios: Do Donors use Joint Cost Allocation Disclosures? Journal of Accounting, Auditing \& Finance, 20, 287-309.

Leftwich, R. W., Watts, R. L. \& Zimmerman, J. L. 1981. Voluntary Corporate Disclosure: The Case of Interim Reporting. Journal of Accounting Research, 19, 50-77. http://dx.doi.org/10.2307/2490984 
Liu, K. \& Arnold, B. R. 2010. Australian superannuation outsourcing - fees, related parties and concentrated markets. Australian Prudential Regulation Authority.

Lopes, P. T. \& Rodrigues, L. L. 2007. Accounting for financial instruments: An analysis of the determinants of disclosure in the Portuguese stock exchange. The International Journal of Accounting, 42, 25-56. http://dx.doi.org/10.1016/j.intacc.2006.12.002

Munir, R., Perera, S. \& Baird, K. 2011. An Analytical Framework to Examine Changes in Performance Measurement Systems within the Banking Sector. Australasian Accounting Business \& Finance Journal, 5, 93-115.

Myners, P. 2000. The Myners Review of Institutional Investment for HM Treasury. UK: HM Treasury.

Sanchez, I.-M. G., Dominguez, L. R. \& Alvarez, I. G. 2011. Corporate governance and strategic information on the internet: A study of Spanish listed companies. Accounting, Auditing \& Accountability Journal, 24, 471-501. http://dx.doi.org/10.1108/09513571111133063

Simpson, A. 2008. Voluntary Disclosure of Advertising Expenditures. Journal of Accounting, Auditing \& Finance, 23, 403-436.

Stewart, F. \& Yermo, J. 2008. Pension Fund Governance: Challenges and Potential Solutions. OECD Working Papers on Insurance and Private Pensions, No. 18, OECD publishing, @ OECD doi: 10.1787/241402256531. http://dx.doi.org/10.1787/241402256531

Stiglitz, J. E. 1979. Equilibrium in Product Markets with Imperfect Information. The Amercian Economic Review, 69, 339-345.

Sy, W., Inman, C., Esho, N. \& Sane, R. 2008. Superannuation fund governance: trustee policies and practices. Melbourne: Australian Prudential Regulation Authority.

Verrecchia, R. E. 1983. Discretionary disclosure. Journal of Accounting and Economics, 5, 179-194. http://dx.doi.org/10.1016/0165-4101(83)90011-3

Wagenhofer, A. 1990. Voluntary disclosure with a strategic opponent. Journal of Accounting and Economics, 12, 341-363. http://dx.doi.org/10.1016/0165-4101(90)90020-5

Watts, R. L. \& Zimmerman, J. L. 1978. Towards a Positive Theory of the Determination of Accounting Standards. The Accounting Review, 53, 112-134.

Dr. Monica Tan is currently a Senior Lecturer in Finance at RMIT University. Her research interests include corporate and fund governance, ownership structure and business networks. She was previously a Risk \& Governance consultant at Deloitte Touche Tohmatsu and Acumen Alliance.

Dr. Marie-Anne Cam is currently a Lecturer in Finance at RMIT University. Her research interests include equity markets, managed funds, superannuation funds and political economy (terrorism and wars). She has professional experience working at Frontier Investment Consulting before joining RMIT University. 
AABFJ | Volume 7, no. 3, 2013 